\title{
Rudanella lutea gen. nov., sp. nov., isolated from an air sample in Korea
}

\author{
Hang-Yeon Weon, ${ }^{1}$ Hyung-Jun Noh, ${ }^{1}$ Jung-A Son, ${ }^{1}$ Han Byul Jang, ${ }^{2}$ \\ Byung-Yong Kim, ${ }^{2}$ Soon-Wo Kwon ${ }^{2}$ and Erko Stackebrandt ${ }^{3}$
}

Correspondence
Soon-Wo Kwon
swkwon@rda.go.k

\begin{abstract}
${ }^{1}$ Applied Microbiology Division, National Institute of Agricultural Science and Technology, Rural Development Administration, Suwon 441-707, Republic of Korea

${ }^{2}$ Korean Agricultural Culture Collection (KACC), Microbial Genetics Division, National Institute of Agricultural Biotechnology, Rural Development Administration, Suwon 441-707, Republic of Korea

${ }^{3} \mathrm{DSMZ}$ - Deutsche Sammlung von Mikroorganismen und Zellkulturen GmbH, Inhoffenstrasse 7b, D-38124 Braunschweig, Germany
\end{abstract}

\begin{abstract}
An orange-coloured bacterial strain, designated $5715 \mathrm{~S}-11^{\top}$, was isolated from an air sample in Suwon, Republic of Korea. The strain was strictly aerobic, Gram-negative, non-spore-forming, non-flagellated and rod-shaped, frequently forming filaments. Growth of the strain was observed at $4-40{ }^{\circ} \mathrm{C}$ (optimum, $30{ }^{\circ} \mathrm{C}$ ), $\mathrm{pH}$ 6.0-8.0 (optimum, $\mathrm{pH} 7.0$ ) and 0-2\% (w/v) $\mathrm{NaCl}$. Phylogenetically, strain $5715 \mathrm{~S}-11^{\top}$ was shown to be a member of the family Spirosomaceae within the phylum Bacteroidetes. Its closest relatives were Spirosoma linguale LMG $10896^{\top}$ (87.9\% 16S rRNA gene sequence similarity) and Larkinella insperata LMG $22510^{\top}$ (86.2 \% 16S rRNA gene sequence similarity). Predominant cellular fatty acids were summed feature 3 $\left(\mathrm{C}_{16: 1} \omega 7 c\right.$ and/or iso- $\left.\mathrm{C}_{15: 0} 2-\mathrm{OH}\right), \mathrm{C}_{16: 1} \omega 5 c$ and iso- $\mathrm{C}_{15: 0}$. Major polar lipids were phosphatidylethanolamine and unknown aminolipids and polar lipids. On the basis of the evidence from this polyphasic study, strain $5715 \mathrm{~S}-11^{\top}$ is considered to represent a novel species of a new genus, for which the name Rudanella lutea gen. nov., sp. nov. is proposed. The type strain of Rudanella lutea is $5715 \mathrm{~S}-11^{\top}\left(=\mathrm{KACC} 12603^{\top}=\mathrm{DSM} 19387^{\top}\right)$.
\end{abstract}

The family Spirosomaceae was first proposed by Larkin \& Borrall (1978). Members of the family are characterized as Gram-negative, non-motile, strictly aerobic, catalase- and oxidase-positive bacteria that produce water-insoluble pigments. As originally defined, the family Spirosomaceae, within the phylum Bacteroidetes, comprised the genera Spirosoma, Flectobacillus and Runella. Another member of the family Spirosomaceae, the genus Larkinella, was proposed by Vancanneyt et al. (2006). The genus Spirosoma, members of which were isolated from freshwater and soil, includes yellow-coloured, gliding bacteria (Larkin \& Borrall, 1984). The genus Larkinella, comprising just Larkinella insperata isolated from water, includes palepink-pigmented, gliding bacteria (Vancanneyt et al., 2006). Cells of species of these two genera are ring-like or horseshoe-shaped.

We isolated strain $5715 \mathrm{~S}-11^{\mathrm{T}}$ from an air sample, and this strain was shown to be phylogenetically related to

The GenBank/EMBL/DDBJ accession number for the $16 \mathrm{~S}$ rRNA gene sequence of strain $5715 S-11^{\top}$ is EF635010.

Cellular fatty acid profiles of strain $5715 \mathrm{~S}-11^{\top}$, Spirosoma linguale DSM $74^{\top}$ and Larkinella insperata LMG $22510^{\top}$ are available as supplementary material with the online version of this paper.
Spirosoma and Larkinella. In the present study, we elucidated the genotypic and phenotypic properties of strain $5715 \mathrm{~S}-11^{\mathrm{T}}$.

An air sample was taken outside in a highly built-up area of Suwon city, Republic of Korea. The air sample was collected with an MAS-100 air sampler (Merck; singlestage multiple-hole impactor) equipped with a Petri dish containing R2A agar (BBL) emended with $200 \mu \mathrm{g}$ cycloheximide $\mathrm{ml}^{-1}$ (Sigma). The Petri dish was incubated at $30{ }^{\circ} \mathrm{C}$ for 5 days, and colonies were selected and purified by using the streak plate method. The pure culture of strain $5715 \mathrm{~S}-11^{\mathrm{T}}$ was transferred to $\mathrm{R} 2 \mathrm{~A}$ medium for further analysis. Cell morphology was examined by using phasecontrast microscopy (AXIO; Zeiss) and transmission electron microscopy with cells grown for 3 days. For transmission electron microscopy, cells were negatively stained with $0.5 \%(\mathrm{w} / \mathrm{v})$ uranyl acetate and examined with a LEO model $912 \mathrm{AB}$ electron microscope. The effects of $\mathrm{NaCl}$ concentration, temperature and $\mathrm{pH}$ on growth were determined at $0,1,2,3$ and $5 \%(\mathrm{w} / \mathrm{v}) \mathrm{NaCl}, 5,10,15,20$, 25, 30, 35, 40 and $45{ }^{\circ} \mathrm{C}$ and $\mathrm{pH} 4,5,6,7,8,9$ and 10 (buffered with citrate-phosphate buffer or Tris/HCl) (Breznak \& Costilow, 1994). The methods of Smibert \& Krieg (1994) were used to test the following basic 
physiological and biochemical characteristics: Gram reaction, oxidase and catalase reaction, deamination of phenylalanine and hydrolysis of casein, DNA, hypoxanthine, starch, Tween 80 and xanthine. Additional hydrolysis tests were also conducted by using $0.1 \%(\mathrm{w} / \mathrm{v})$ CM-cellulose, $1 \%(\mathrm{w} / \mathrm{v})$ chitin from crab shells, $0.5 \%$ $(\mathrm{w} / \mathrm{v})$ pectin and $0.5 \%(\mathrm{w} / \mathrm{v})$ tyrosine. Flexirubin-type pigments were detected based on a colour shift after exposure to a $20 \%(\mathrm{w} / \mathrm{v}) \mathrm{KOH}$ solution (Reichenbach, 1992). Gliding motility was observed by oil-immersion phase-contrast microscopy of the edge of colonies after cultivation on R2A at $30{ }^{\circ} \mathrm{C}$ for 2 days. Anaerobic growth was checked by using a BBL anaerobic jar (Becton Dickinson). Growth on peptone water was checked by using $0.2 \%$ Bacto peptone (Difco) in distilled water. The strain was also characterized via API 20NE, API ID 32GN and API ZYM test strips (bioMérieux), according to the manufacturer's recommendations. Cells of strain 5715S$11^{\mathrm{T}}$ were strictly aerobic, non-motile and rod-shaped, frequently forming filaments $(0.7-1 \mu \mathrm{m}$ wide and 2.5$50 \mu \mathrm{m}$ long) (Fig. 1). Colonies were orange-coloured, convex and circular with clear margins. The strain was able to grow on R2A and nutrient agar (Difco), but not on trypticase soy agar (Difco) or MacConkey agar (Difco). Additional phenotypic characteristics that could be used to differentiate between strain $5715 \mathrm{~S}-11^{\mathrm{T}}$ and the type strains of its closest phylogenetic neighbours (Spirosoma linguale and $L$. insperata; see below) are shown in Table 1.

The following chemotaxonomic characteristics were analysed: fatty acids (according to the standard protocol of the MIDI/Hewlett Packard Microbial Identification System; Sasser, 1990), phospholipids (Minnikin et al., 1984) and $\mathrm{G}+\mathrm{C}$ content of the DNA (Mesbah et al., 1989). Dominant fatty acids were summed feature $3\left(\mathrm{C}_{16: 1} \omega 7 c\right.$ and/or iso$\left.\mathrm{C}_{15: 0} \quad 2-\mathrm{OH} ; \quad 29.4 \%\right), \quad \mathrm{C}_{16: 1} \omega 5 c \quad(17.7 \%)$, iso- $\mathrm{C}_{15: 0}$ $(14.3 \%)$, iso- $\mathrm{C}_{17: 0} \quad 3-\mathrm{OH}(9.7 \%)$ and anteiso- $\mathrm{C}_{15: 0}$

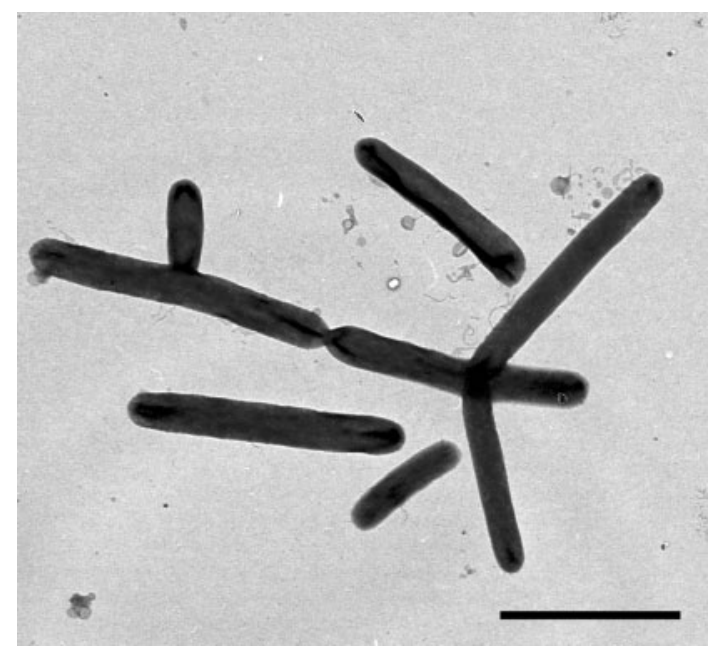

Fig. 1. Transmission electron micrograph of cells of strain 5715S$11^{\top}$ grown on R2A for 3 days. Bar, $5 \mu \mathrm{m}$.
(7.7\%) (see Supplementary Table S1, available in IJSEM Online). The polar lipid profile of strain $5715 \mathrm{~S}-11^{\mathrm{T}}$ consisted of phosphatidylethanolamine, several unknown aminolipids and polar lipids and one unknown phospholipid (Fig. 2). The DNA G + C content of strain $5715 \mathrm{~S}-11^{\mathrm{T}}$ was $55 \mathrm{~mol} \%$.

Genomic DNA was isolated by the method of Ausubel et al. (1987). The 16S RNA gene sequence of strain $5715 \mathrm{~S}-11^{\mathrm{T}}$ was analysed as described by Kwon et al. (2003). The sequence obtained was compared against reference $16 \mathrm{~S}$ rRNA gene sequences available in the GenBank database. Phylogenetic analysis was carried out by using the MEGA 3 program (Kumar et al., 2004), after multiple alignments of the data via the CLUSTAL $\mathrm{w}$ program (Thompson et al., 1994). Phylogenetic dendrograms were constructed by using the neighbour-joining (Saitou \& Nei, 1987) and maximum-parsimony (Fitch, 1971) methods with bootstrap values based on 1000 replications. According to BLAST search results, strain $5715 \mathrm{~S}-11^{\mathrm{T}}$ was shown to be a member of the family Spirosomaceae. It shared highest $16 \mathrm{~S}$ rRNA gene sequence similarities ( 87.9 and $86.2 \%$, respectively) with S. linguale LMG $10896^{\mathrm{T}}$ and L. insperata LMG $22510^{\mathrm{T}}$. It showed less than $83 \%$ 16S rRNA gene sequence similarity to the type strains of all other recognized species examined. In a neighbour-joining tree based on 16S rRNA gene sequences, strain $5715 \mathrm{~S}-11^{\mathrm{T}}$ formed a compact cluster with S. linguale LMG $10896^{\mathrm{T}}$ and L. insperata LMG $22510^{\mathrm{T}}$ with high bootstrap support (100\%; Fig. 3). A tree based on maximum-parsimony analysis revealed a similar result.

In conclusion, strain $5715 \mathrm{~S}-11^{\mathrm{T}}$ can be differentiated clearly from its closest phylogenetic neighbours, $S$. linguale and $L$. insperata. $16 \mathrm{~S}$ rRNA gene sequence analysis showed that strain $5715 \mathrm{~S}-11^{\mathrm{T}}$ showed very low sequence similarities $(\leqslant 87.9 \%)$ to the type strains of $S$. linguale and $L$. insperata, much lower than the threshold level that is generally used to define a new genus (Ludwig et al., 1998). Cells of strain $5715 \mathrm{~S}-11^{\mathrm{T}}$ lacked the morphology (ring-like, horseshoe-shaped, coiled or helical) characteristic of cells of $S$. linguale and $L$. insperata. The polar lipid profile of strain $5715 \mathrm{~S}-17^{\mathrm{T}}$ lacked aminophospholipid APL1, aminolipid AL3 and phospholipid PL1, the major components found for S. linguale and L. insperata (Fig. 2). Strain 5715S$11^{\mathrm{T}}$ could also be differentiated from $S$. linguale and $L$. insperata on the basis of several physiological properties, including substrate assimilation patterns (Table 1). Therefore, we suggest that strain $5715 \mathrm{~S}-11^{\mathrm{T}}$ represents a novel species of a new genus, for which the name Rudanella lutea gen. nov., sp. nov. is proposed.

\section{Description of Rudanella gen. nov.}

Rudanella (Ru.da.nel'la. L.L. dim. suff. -ella; N.L. fem. dim. n. Rudanella arbitrary name, after RDA, Rural Development Administration, where taxonomic studies of this taxon were conducted).

Cells are strictly aerobic, Gram-negative, non-motile, nonspore-forming rods, frequently forming filaments. 
Table 1. Differential phenotypic characteristics between strain $5715 \mathrm{~S}-11^{\top}$, Spirosoma linguale and Larkinella insperata

Strains: 1 , strain $5715 \mathrm{~S}-11^{\mathrm{T}} ; 2$, S. linguale DSM $74^{\mathrm{T}} ; 3$, L. insperata LMG $22510^{\mathrm{T}}$. Data were obtained in the present study unless indicated. All three strains were positive for $\beta$-galactosidase and negative for indole production, glucose fermentation, arginine dihydrolase and urease. All strains were negative for assimilation of D-mannitol, potassium gluconate, capric acid, adipic acid, malic acid, trisodium citrate and phenylacetic acid. All were positive for alkaline phosphatase, esterase (C4), esterase lipase (C8), leucine arylamidase, valine arylamidase, cystine arylamidase, acid phosphatase, naphthol-AS-BI-phosphohydrolase, $\beta$-glucosidase, $N$-acetyl- $\beta$-glucosaminidase and $\beta$-mannosidase, but negative for lipase (C14), $\beta$-glucuronidase and $\alpha$-fucosidase. + , Positive; $(+)$, weakly positive; - , negative.

\begin{tabular}{|c|c|c|c|}
\hline Characteristic & 1 & 2 & 3 \\
\hline Isolation source & Air & Freshwater, soil ${ }^{\star}$ & Water $\dagger$ \\
\hline Colony colour & Orange & Yellow & Pale pink \\
\hline Cell morphology & $\begin{array}{l}\text { Straight rods and } \\
\text { filaments }\end{array}$ & $\begin{array}{l}\text { Ring-like and horseshoe-shaped; filaments, coils } \\
\text { and helices may be present }{ }^{*}\end{array}$ & $\begin{array}{l}\text { Ring-like and } \\
\text { horseshoe-shaped } \dagger\end{array}$ \\
\hline Growth on peptone water & $(+)$ & - & - \\
\hline Nitrate reduction & - & + & - \\
\hline \multicolumn{4}{|l|}{ Hydrolysis of: } \\
\hline Aesculin & - & + & + \\
\hline Gelatin & - & + & + \\
\hline Starch & + & $(+)^{*}$ & $-\dagger$ \\
\hline \multicolumn{4}{|l|}{ Assimilation of (API 20NE): } \\
\hline D-Glucose & - & + & + \\
\hline L-Arabinose & - & + & - \\
\hline D-Mannose & - & + & + \\
\hline$N$-Acetylglucosamine & - & + & + \\
\hline Maltose & - & + & + \\
\hline \multicolumn{4}{|l|}{ Enzymic activities (API ZYM) } \\
\hline Trypsin & - & + & + \\
\hline$\alpha$-Chymotrypsin & - & + & + \\
\hline$\alpha$-Galactosidase & - & + & + \\
\hline$\beta$-Galactosidase & - & + & + \\
\hline$\alpha$-Glucosidase & - & + & + \\
\hline DNA G $+C$ content $(\mathrm{mol} \%)$ & 55 & $51-53^{\star}$ & $53 \dagger$ \\
\hline
\end{tabular}

${ }^{*}$ Data for the species from Larkin \& Borrall (1984).

$\dagger$ Data from Vancanneyt et al. (2006).
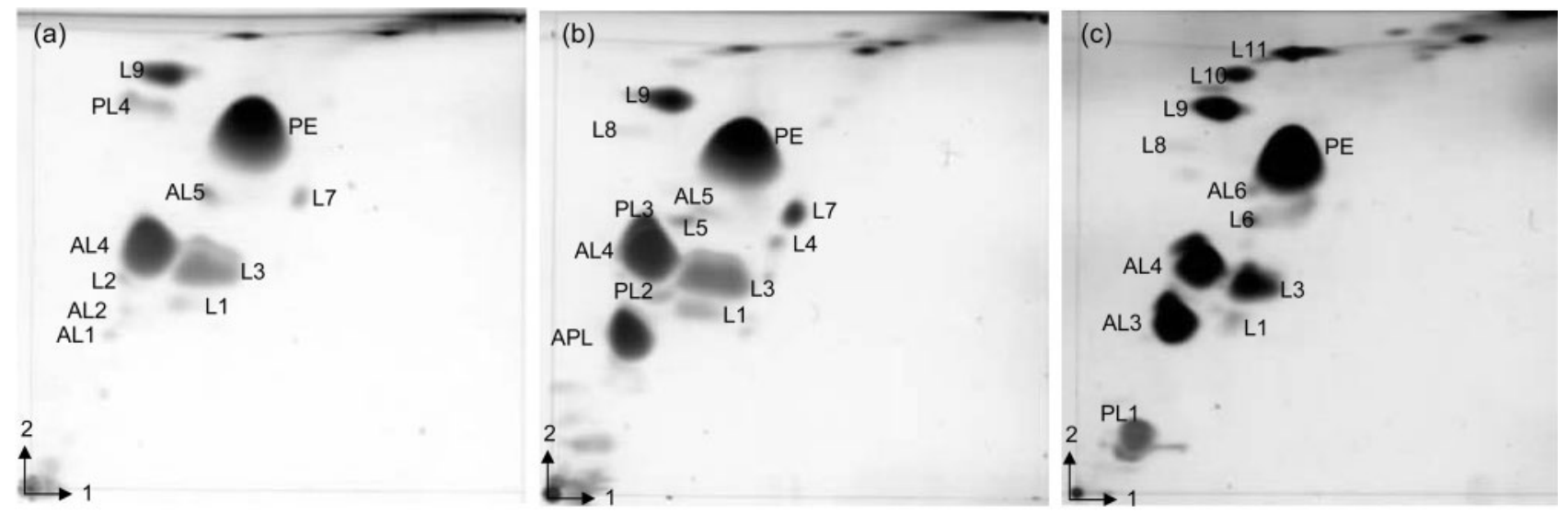

Fig. 2. Two-dimensional thin-layer chromatographs of polar lipid extracts obtained from strains $5715 \mathrm{~S}-11^{\top}$ (a), Spirosoma linguale DSM $74^{\top}$ (b) and Larkinella insperata LMG $22510^{\top}$ (c) sprayed with anisaldehyde. L1-L11, Unidentified polar lipids; AL1-AL6, unidentified aminolipids; PL1-PL4, unidentified phospholipids; APL, unidentified aminophospholipid. 


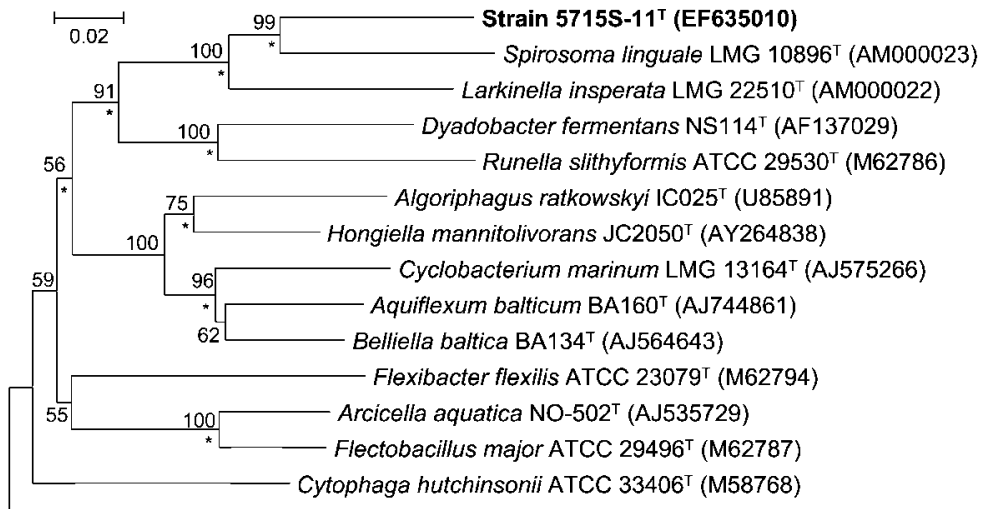

Chitinophaga pinensis ACM 2034 ${ }^{\top}$ (AF078775)
Fig. 3. Neighbour-joining tree based on $16 \mathrm{~S}$ rRNA gene sequences showing the phylogenetic relationships between strain $5715 \mathrm{~S}-11^{\top}$ and some members of the phylum Bacteroidetes. Asterisks indicate that the corresponding branches were also recovered in the maximum-parsimony tree. Bar, 0.02 changes per nucleotide position.
Oxidase- and catalase-positive. Nitrate is not reduced. No flexirubin-type pigments are produced. Predominant cellular fatty acids are summed feature $3\left(\mathrm{C}_{16: 1} \omega 7 c\right.$ and/ or iso- $\left.\mathrm{C}_{15: 0} 2-\mathrm{OH}\right), \mathrm{C}_{16: 1} \omega 5 c$ and iso- $\mathrm{C}_{15: 0}$. Major polar lipids are phosphatidylethanolamine and unknown aminolipids and polar lipids. Phylogenetically, the genus belongs to the family Spirosomaceae within the phylum Bacteroidetes. The type species is Rudanella lutea.

\section{Description of Rudanella lutea sp. nov.}

Rudanella lutea (lu'te.a. L. fem. adj. lutea orangecoloured).

Cells frequently form filaments that are $0.7-1 \mu \mathrm{m}$ wide and $2.5-50 \mu \mathrm{m}$ long. Colonies are orange-coloured, convex and circular with clear margins after 3 days cultivation on R2A. The $\mathrm{pH}$ range for growth is 6.0-9.0, with an optimum at $\mathrm{pH}$ 7.0. The temperature range for growth is $5-40{ }^{\circ} \mathrm{C}$, with an optimum at $30^{\circ} \mathrm{C}$. Growth occurs at $\mathrm{NaCl}$ concentrations of $0-2 \% \quad(\mathrm{w} / \mathrm{v})$. No gliding motility is observed. Hydrolyses casein, tyrosine, Tween 80 and starch, but not chitin, CM-cellulose, DNA, hypoxanthine, pectin or xanthine. In API $20 \mathrm{NE}$ test strips, cells are positive only for $\beta$-galactosidase. Negative for nitrate reduction, indole production, glucose fermentation, arginine dihydrolase, urease, aesculin hydrolysis and gelatin hydrolysis. In API 20NE and API ID 32GN test strips, assimilates only glycogen. In API ZYM tests, cells are positive for alkaline phosphatase, esterase (C4), esterase lipase (C8), leucine arylamidase, valine arylamidase, cystine arylamidase, acid phosphatase, naphthol-AS-BI-phosphohydrolase, $\beta$-glucosidase, $N$-acetyl- $\beta$-glucosaminidase and $\alpha$-mannosidase. Negative for lipase (C14), trypsin, $\alpha$-chymotrypsin, $\alpha$-galactosidase, $\beta$-galactosidase, $\beta$-glucuronidase, $\alpha$-glucosidase and $\alpha$-fucosidase. The DNA G $+\mathrm{C}$ content of the type strain is $55 \mathrm{~mol} \%$ (HPLC).

The type strain, $5715 \mathrm{~S}-11^{\mathrm{T}}$ (=KACC $12603^{\mathrm{T}}=\mathrm{DSM}$ $\left.19387^{\mathrm{T}}\right)$, was isolated from an air sample from Suwon City, Republic of Korea.

\section{Acknowledgements}

This study was supported by the National Institute of Agricultural Biotechnology (NIAB grant no. 06-4-11-19-1), Rural Development Administration, Republic of Korea.

\section{References}

Ausubel, F. M., Brent, R., Kingston, R. E., Moore, D. D., Seidman, J. G., Smith, J. A. \& Struhl, K. (1987). Current Protocols in Molecular Biology. New York: Wiley.

Breznak, J. A. \& Costilow, R. N. (1994). Physicochemical factors in growth. In Methods for General and Molecular Bacteriology, pp. 137154. Edited by P. Gerhardt, R. G. E. Murray, W. A. Wood \& N. R. Krieg. Washington, DC: American Society for Microbiology.

Fitch, W. M. (1971). Toward defining the course of evolution: minimum change for a specific tree topology. Syst Zool 20, 406-416.

Kumar, S., Tamura, K. \& Nei, M. (2004). MEGA3: integrated software for molecular evolutionary genetics analysis and sequence alignment. Brief Bioinform 5, 150-163.

Kwon, S.-W., Kim, J.-S., Park, I.-C., Yoon, S.-H., Park, D.-H., Lim, C.-K. \& Go, S.-J. (2003). Pseudomonas koreensis sp. nov., Pseudomonas umsongensis sp. nov. and Pseudomonas jinjuensis sp. nov., novel species from farm soils in Korea. Int J Syst Evol Microbiol 53, 21-27.

Larkin, J. M. \& Borrall, R. (1978). Spirosomaceae, a new family to contain the genera Spirosoma Migula 1894, Flectobacillus Larkin et al. 1977, and Runella Larkin and Williams 1978. Int J Syst Bacteriol 28, 595-596.

Larkin, J. M. \& Borrall, R. (1984). Family I. Spirosomaceae Larkin and Borrall 1978, 595 ${ }^{\mathrm{AL}}$. In Bergey's Manual of Systematic Bacteriology, vol. 1, pp. 125-126. Edited by N. R. Krieg \& J. G. Holt. Baltimore: Williams \& Wilkins.

Ludwig, W., Strunk, O., Klugbauer, S., Klugbauer, N., Weizenegger, M., Neumaier, J., Bachleitner, M. \& Schleifer, K. H. (1998). Bacterial phylogeny based on comparative sequence analysis. Electrophoresis 19, 554-568.

Mesbah, M., Premachandran, U. \& Whitman, W. B. (1989). Precise measurement of the $\mathrm{G}+\mathrm{C}$ content of deoxyribonucleic acid by highperformance liquid chromatography. Int J Syst Bacteriol 39, 159-167.

Minnikin, D. E., O’Donnell, A. G., Goodfellow, M., Alderson, G., Athalye, M., Schaal, A. \& Parlett, J. H. (1984). An integrated procedure for the extraction of isoprenoid quinones and polar lipids. J Microbiol Methods 2, 233-241. 
Reichenbach, H. (1992). The order Cytophagales. In The Prokaryotes. A Handbook on the Biology of Bacteria: Ecophysiology, Isolation, Identification, Applications, 2nd edn, pp. 3631-3675. Edited by A. Balows, H. G. Trüper, M. Dworkin, W. Harder \& K. H. Schleifer. New York: Springer.

Saitou, N. \& Nei, M. (1987). The neighbor-joining method: a new method for reconstructing phylogenetic trees. Mol Biol Evol 4, 406-425.

Sasser, M. (1990). Identification of bacteria by gas chromatography of cellular fatty acids, MIDI Technical Note 101. Newark, DE: MIDI Inc.

Smibert, R. M. \& Krieg, N. R. (1994). Phenotypic characterization. In Methods for General and Molecular Bacteriology, pp. 607-654. Edited by P. Gerhardt, R. G. E. Murray, W. A. Wood \& N. R. Krieg. Washington, DC: American Society for Microbiology.

Thompson, J. D., Higgins, D. G. \& Gibson, T. J. (1994). CLUSTAL W: improving the sensitivity of progressive multiple sequence alignment through sequence weighting, position-specific gap penalties and weight matrix choice. Nucleic Acids Res 22, 4673-4680.

Vancanneyt, M., Nedashkovskaya, O. I., Snauwaert, C., Mortier, S., Vandemeulebroecke, K., Hoste, B., Dawyndt, P., Frolova, G. M., Janssens, D. \& Swings, J. (2006). Larkinella insperata gen. nov., sp. nov., a bacterium of the phylum 'Bacteroidetes' isolated from water of a steam generator. Int J Syst Evol Microbiol 56, 237-241. 